\title{
ANALYIS OF WEBSITES IN EVENT MANAGEMENT
}

\author{
Juraj Puljić \& Božidar Jaković \& Ivan Strugar
}
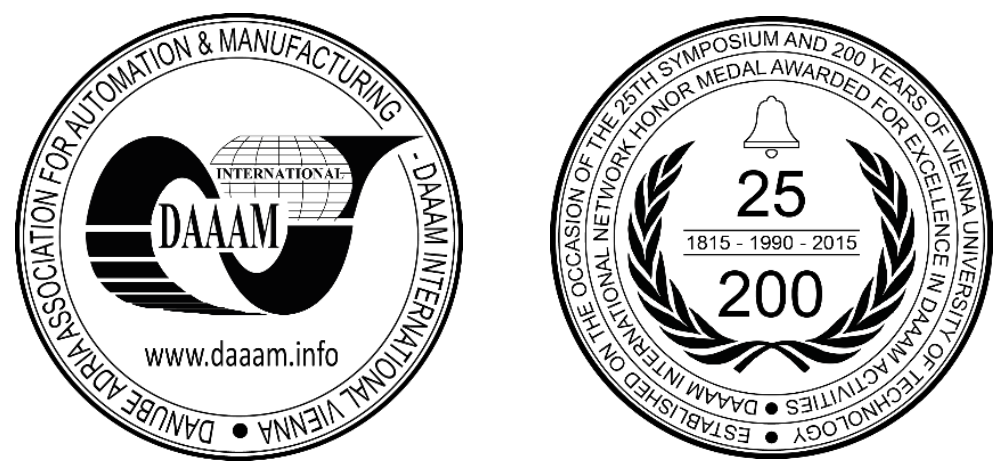

This Publication has to be referred as: Puljic, J[uraj]; Jakovic, B[ozidar] \& Strugar, I[van] (2017). Analysis of Websites in Event Management, Proceedings of the 28th DAAAM International Symposium, pp.0035-0043, B. Katalinic (Ed.), Published by DAAAM International, ISBN 978-3-902734-11-2, ISSN 1726-9679, Vienna, Austria DOI: $10.2507 / 28$ th.daaam.proceedings.005

\begin{abstract}
The event management industry has become very close to technology recently, and there are no signs of that relationship slowing down. Electronic and other online services have become a necessity, and are no longer considered luxury, because we are living life too fast. The services that event management organizations offer today are mostly transacted online. This paper will show a detailed analysis that provides answers to various user experience related questions in the interaction with Croatian and global event management related websites and pages. The research also displays the top Croatian and global organizations that meet the criteria presented in the paper. The study is based on an analysis of a large number of global websites - both national and international - associated with event organization, and it answers some questions users might have during the use of the website or mobile application. The contents of 200 websites and applications related to event management have been analyzed for the purposes of showing the trends and possibilities in the digital event organization industry, as well as the availability and functionality of the services the organizations provide. This was done by analyzing over 100 attributes for each website.
\end{abstract}

Keywords: Internet; Digital Business; Event Management; Event Organization

\section{Introduction}

Today, companies across all industries are required to go digital with their businesses in some part, if not completely, and so is the event management industry. The purpose of this thesis is to analyze different Web services associated with event management and show the possibilities of a digitized event organization and management. This thesis additionally shows the development of a mobile application whereby every user can get an insight into every aspect of the event they are attending, giving them the chance to fully immerse themselves in the event instead of wasting time on secondary activities, e.g. standing in lines while waiting for a drink. The possibilities include: checking for and booking of the closest service required through the use of sensors (e.g. locking the closest toilet), looking at the situation of the event through drone cameras (especially useful if there are multiple stages during a concert, to see what one is missing), etc.

\section{Development and application of electronic business}

The notion of business as we knew it for thousands of years started to change around 1995. Namely, the Internet had been around for some time, but no one really understood its possible applications in real life, except for connecting 
military and educational centers within countries, and later around the world [1]. However, at that time, due to an exponential rise in the use of personal computers, e-business had started to prosper: it had come to be a modern business model that applies IT and Internet technology to transact and perform key business activities [2]. The term e-business was coined by IBM as an attempt to brand their Internet business services, but the term had become so wildly popular and ubiquitous that they could no longer differentiate by using it, since a whole new industry had been born with that name.

Even though the terms digital business and e-commerce are often used interchangeably, since both of them are understood as using the electronic technology to do business, this use is incorrect [3]. That is to say, digital business is the broader concept of the two, as it covers all business processes that take action online, while e-commerce is limited to buying and selling through the use of electronic technology [4]. An example of e-commerce would be a Web page or Webshop that lets its users buy online, where a company on the one side sells a product or service, and the buyer buys it [5]. On the other hand, e-business would also entail e-mail marketing to existing or potential new buyers; online system that keeps track of the warehouse conditions and sends signals electronically; CMS (content management systems) that maintain and manage the flow of information between editors, publishers, programmers and managers; online program that automatizes the induction of new employees into the register and supplies information, etc. [6][7] Therefore, ebusiness is a broad term that includes any business process that is done through electronic technology, while e-commerce is but a part of e-business that deals with electronic transactions, i.e. buying and selling online [8]. As technology and business develop, we slowly but surely cross from e-business toward d-business, i.e. digital business. That would entail the creation of new revenue and value through the yet non-existent combinations of people, businesses and things [9]. For example, if Nike somehow received the information about the number of miles their user had run in one day or through a period of time, and sent that same user a new pair of sneakers when the time comes for a new pair (fitting them personally) based on that information, that would be d-business [10][11]. Even though the advent of electronic business has enabled many economic advancements, there are some negative aspects as well [12].

One of the negative sides of electronic business is the ease of business consolidation and the disappearance of SMEs and brick-and-mortar businesses, which brings about income disparity [13]. As an adequate example, Hilton employs more than 150,000 people and had a market value only two times higher than Airbnb as of 2014, and Airbnb only employs 700 people.

There is also the question of Internet security [14]. Since the access to electronic businesses has been made easy thanks to the Internet, there are more people who can get inside and that carries more security risk [15]. All stakeholders of a business, from buyers and suppliers to employees, use and have access to the electronic system, and there is a lot of data circulating that should be saved safely [16]. Therefore, hackers pose a considerable threat for e-business since they can get unauthorized access to sensitive data and endanger the business and all of its stakeholders. For that reason, companies that use electronic business should put in effort and resources to disable and prevent such hacking attacks to enable secure data transmission. This is where firewall usually comes in handy [17].

The most frequent ways of protection are antivirus programs, and they are very necessary today. They protect data and enable secure data transmission [18]. To protect a business from unauthorized third-party access, firewall is frequently used. It logs login attempts and notifies the administrators, so it limits the access on private networks, as well as public networks that businesses use [19].

Encryption is the part of cryptography that deals with coding, i.e. turning messages into unreadable code. For those messages to be read or usable, decryption is needed. Thanks to encryption, it is easier to make sure that the data sent will be used fort he intended purposes, as the addressee receives a key which decrypts the message. Digital certificates are a way to determine the identity of the document owner [20]. In that way, it is ensured that the employees will not open a document (a potential threat) that doesn't belong to the company, as hackers could be given a way in without anyone knowing. There are many other ways to protect an e-business, but these were the most usual ones [21].

Electronic business is one of the latest examples that show that business is not a static, but a very dynamic process where constant innovation and investment in research is a necessity [22]. Technology is making adaptation very hard, as it changes faster and faster every day and requires an even faster environment change. For that reason, e-business is making life easier and faster, i.e. making business simpler and faster by eliminating unnecessary bureaucracy, leaving us with more free time. Competition adds to that, since it makes businesses better and more efficient by trying to outdo them, which is a healthy phenomenon. The more competition there is, the fewer resources buyers have to give up to get what they want, and businesses have to try harder for the buyers to choose them instead of someone else.

One of the main technologies that came to be in the digital revolution is cloud computing. That is remote data storage, whereby data can be accessed through computer networks, storage media and software applications, which makes it so that users don't have to carry their own hard disks with them wherever they go, but they can access their data anywhere in the world as long as they are connected to the Internet. That means less investment in servers and their maintenance for companies that only used them as a support for their key activities. They can now pay for the cloud server service and focus on their business [23].

Web 2.0 is a development of the World Wide Web, which was static in the beginning and could be meddled with only by the technically sound users. With Web 2.0, creation and collaboration were channeled to average users, where they lead the way. The focus is on social media and communication, as opposed to solely reading the existent information. So, the content is created by the end users, and examples include Facebook, where anyone can post a status update that another person can like, tag, add hashtags, etc. Web 2.0. simply is a collaborative medium where businesses can get closer to their buyers [24]. 
The Internet of Things is another modern technology that is associated with electronic business, and it is special because it connects machines to machines, so that they can communicate without the need for humans [25]. For now, this is limited to smart homes: for example, a fridge connected to a phone can find out what frequent groceries are missing and add them to a smartphone's to-do list, which enables the connection between the seller and buyer, where the seller can send the buyer the groceries at that moment, without the buyer even being aware of all the processes that had happened. The possibilities are endless: in the future, people won't need to program machines, as they will be able to program and fix and update themselves. On the other hand, this brings about the scary thought of machine superiority over humans. But the focus should remain on the positive, such as smart cities that would eliminate and reduce waste and increase efficiency in every aspect of our lives.

Another big technology that is applicable in electronic business is mobile. Surprisingly, the continent that makes mostuse of this technology is Africa, where m-banking has developed due to a safer, cheaper and easier money transfer [26][27]. Namely, mobile technology enables micro-loans, which are especially useful in the rural parts of the Earth and enable SMEs. All transactions go through digitally so there is no waiting, as everything is happening in real time [28]. Mobile or smart phone could be also used as a remote real system for monitoring and control [29].

\section{Methodology and Sample Description}

As the basis for conducting this research, use was made of the list of event management websites. The list was made by authors using Web mining techniques. Most of the data were collected from the websites of the event management websites covered by this research. All the data were collected in the period from 01 August 2017 (the beginning of the research) to 15 September 2017. There are used descriptive statistics methods, as well as inductive conclusions. A new model for analysing event management websites was presented by authors (Figure 1). Similar model Spremić et al. presented in their paper, but it was applied on hotel websites [30]. All event management websites should be viewed through five main forms: (1) Website content, (2) Social Networks and Web 2.0, (3) Public Relations and User Support, (4) Multimedia and Mobile technologies and (5) User Experience and Technical Specification. The central part of the research analyses the websites of event management websites with particular regard to that model.

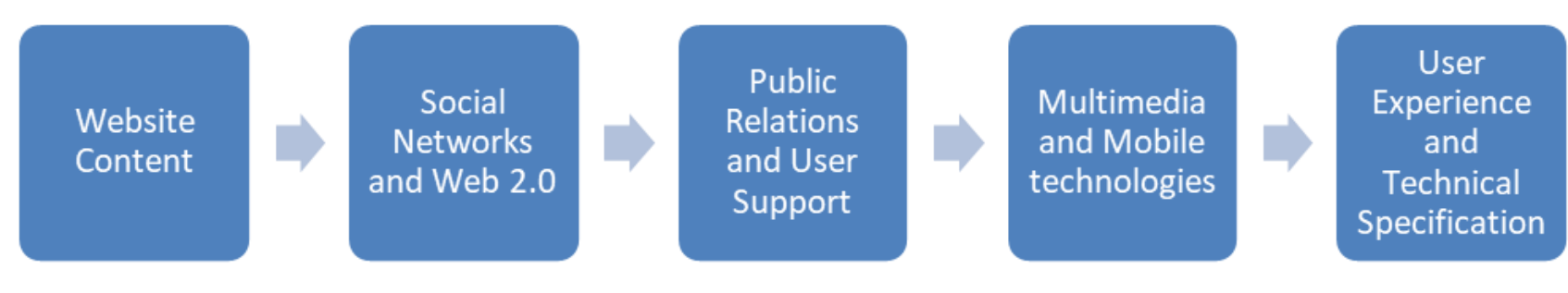

Fig. 1. Model for analysing Event Management Websites

The research was done so that every out of 200 websites which were found on the Google Search Engine (and suited the content which was collected on other similar websites) while searching for the terms such as "event organizations in Croatia", etc. were allocated 103 attributes or criteria, and were graded with the Boolean expression, i.e. 0 or 1 , if they didn't or did have a certain attribute.

In the end, the result was the list of the best and the worst graded websites, along with their respective points. Altogether, there were 17 organisations' websites analyzed from the Republic of Croatia, 150 organizations from the United States of America, 16 websites from the United Kingdom, 5 websites from Australia, 5 websites from Canada, 3 websites from the Republic of Ireland, 2 organisation websites from the South African Republic, 1 organisation website from Austria and 1 organisation website from India.

\section{Event Management Websites - Research Results}

This research shows the suitability and the availability of services connected to event organisation through the Internet around the world. The observed criteria/attributes are the following: Visible logo, Search Engine, About the organisation, Contact, Slogan, Telephone number, Toll free phone, Fax, E-mail, Headquarters, existence of a physical office, Locations, Locations with a built in map, Account log in (sign up/log in), Pop-up window, Facebook link on the website, Twitter link on the website, Google+ link on the website, LinkedIn link on the website, YouTube link on the website, Instagram link on the website, Vimea link on the website, Pinterest link on the website, Identification Number, Personal Identification Number, Giro-account, Working hours, sitemap, Useful links, Praises, Suggestions and complaints (feedback), Calendar of events, Notices about upcoming events, Notices about finished events, Terms of use, Privacy, 
Facebook, Number of Facebook friends ( in thousands), Twitter, Number of Twitter followers (in thousands), Google+, Number of Google+ followers (in hundreds), LinkedIn, Number of LinkedIn followers (in hundreds), Instagram, Number of Instagram followers (in thousands), RSS, Flickr, Youtube, Number of YouTube views (in thousands), Chat, Blog, Promptness of the blog, English, German, French, Spanish, Italian, organisation's domain, .hr, .com, .com.hr, .co.uk, .com.au, .ca, and others, Links to your website, to other Web pages, Media communication, Newsletter, Corporate Social Responsibility, Customer Support, Information department, Through chat service, Through the telephone, Through email, Support 24/7, Mission, Vision, Goals, Photos, Video content, Animations, Existence of the organisation's logo, Functionality on mobile devices, Special adaptation of websites for mobile devices, iOS, Android, Windows phone, Performance grade is above $80 \%$, Loading time of the homepage is under 3 seconds, Size of the homepage is under 5 $\mathrm{MB}$, Bounce rate is under 50\%, Global rank is under 500.000, Rank in the country of origin is under 5.000, Authority of the homepage is over 50, Authority of the domain is over 50, HTML, ASP, PHP, Flash, Java, Secure HTTP (HTTPS) and other.

User experience included an analysis using the tools like http://tools.pingdom.com, https://www.alexa.com/siteinfo and http://moz.com. The goal of the analysis was to process and show my own research in detail and give recommendations based on the conducted research (Figures 2-7).

Figure 2 shows the disambiguation of the websites' content, and we can see that pop-up windows pop up on 46 (25\%) of websites, as opposed to 0 in Croatia. The pop-up windows give an opportunity to the organizations that use them to collect information, such as e-mail addresses, from their users.

The privacy policy is present on 152 websites (83\%), and terms \& conditions are present on 163 websites (89\%) numbers that clearly show that both are taken more seriously in the rest of the world than in Croatia. A field with events that are coming up, as well as past events, was present on 43 websites (23\%), and an events calendar was shown on 31 websites (17\%). The ability to give feedback, complain and commend was present on 41 websites $(22 \%)$, which shows that it is another factor taken more seriously outside of Croatia. Further, 21 websites (11\%) saw the importace of links when ranking in search engines, and the sitemap was used in 11 cases $(6 \%)$.

The working time was shown on 17 websites (9\%), the giro-account information on 13 websites (7\%), PIN on 22 websites (12\%), and the ID number on 45 websites (45). According to this information, it is obvious that foreign websites leave less space for the bureaucratic information, and focus more on the Web site user. The reason for that could be the foreign legislation, as in some instances it is still necessary for Croatian companies to show the bureaucratic information online, which is in reality useless to the users.

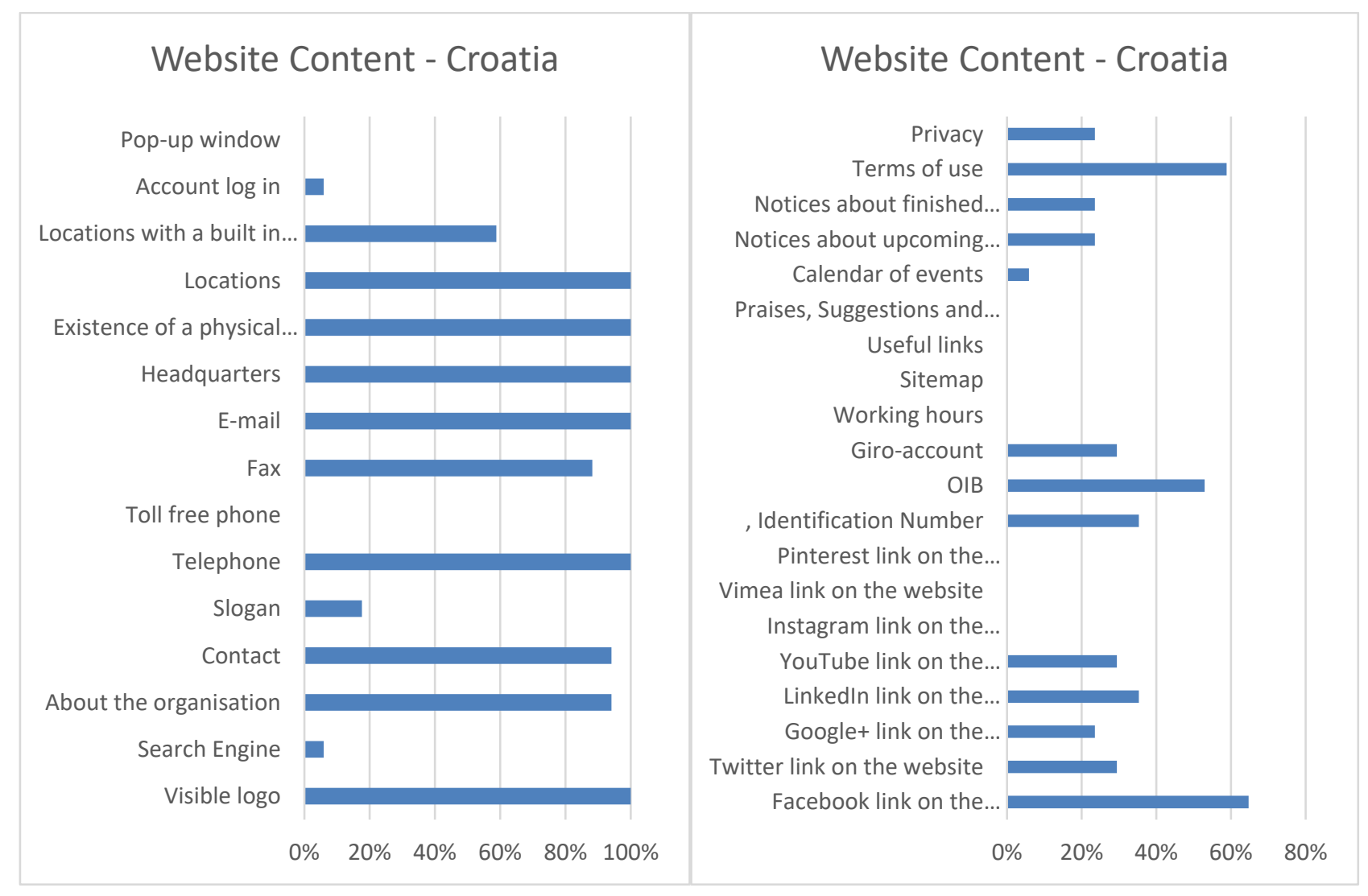




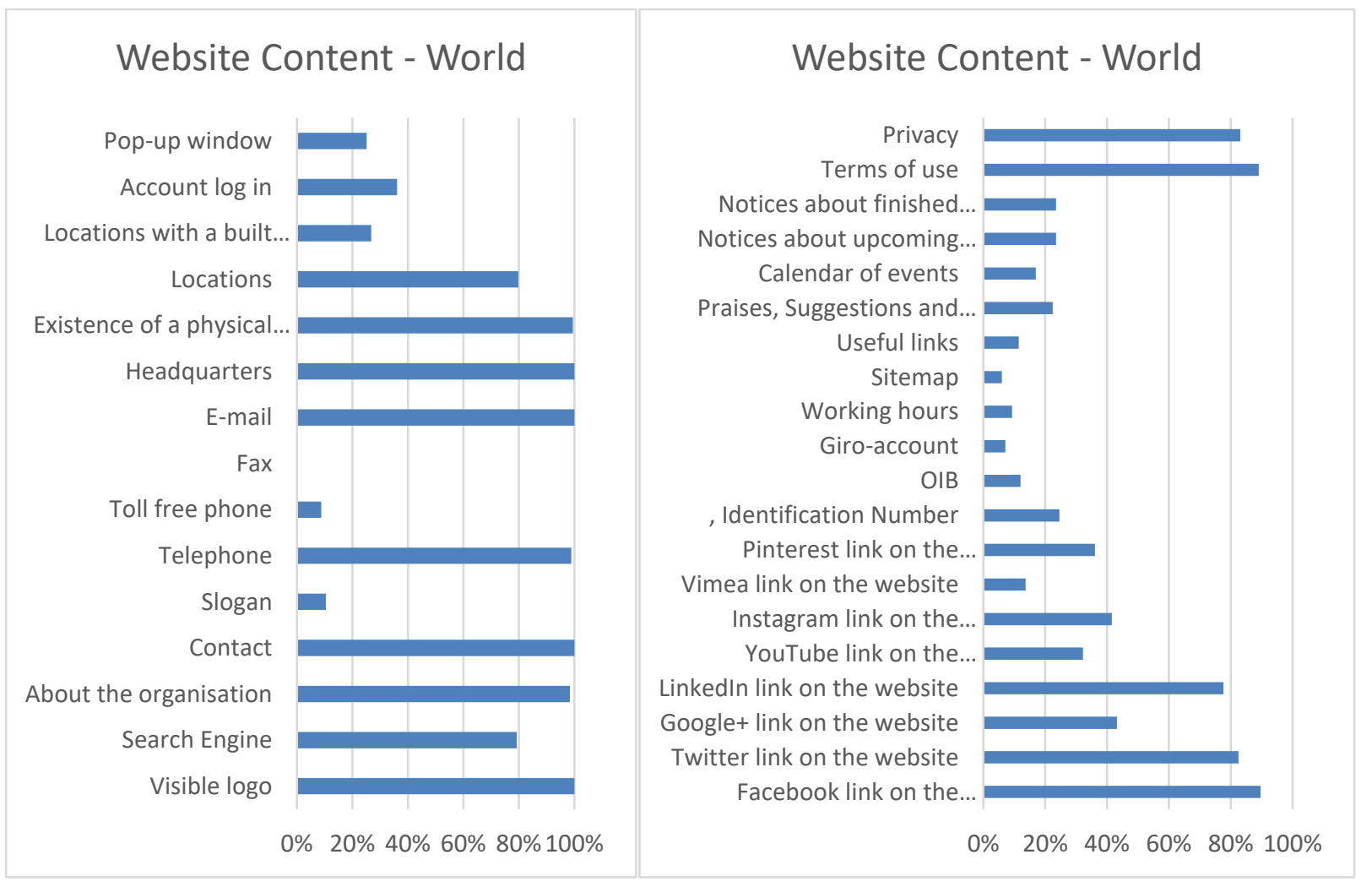

Fig. 2. Website Content

As for social media links, it can be seen that the foreign companies, as opposed to the Croatian ones, have found value in using the newer applications, such as Pinterest and Vimeo. 66 websites (36\%) had a Pinterest link on their websites, and $25(14 \%)$ had a Vimeo link. Instagram is another popular service, as 76 websites (42\%) had an Instagram link on their websites, which is almost half of all the analyzed foreign websites. YouTube was linked by 59 websites (32\%), Google+ by 79 (43\%), and the most linked social media were Facebook with 164 websites (90\%) and LinkedIn with 142 (78\%).

Figure 3 shows the organizational presence on social media and Web 2.0. As per these data, the most organizations had a Twitter profile - 169 (92\%), followed by Facebook - 164 (90\%) and LinkedIn - $148(81 \%)$. As in Croatia, many organizations have Google+ profiles $-88(48 \%)$. Every organization that had an Instagram account linked to it -76 (42\%). 66 organizations had a YouTube account (36\%), 1 had Flickr (1\% - which is $100 \%$ more than the Croatian organizations). 28 websites (15\%) had the chat option, and 183 websites (100\%, all of them) had a blog. However, only 142 of those (78\%) had an up to date blog, which means at least one post in August 2017.

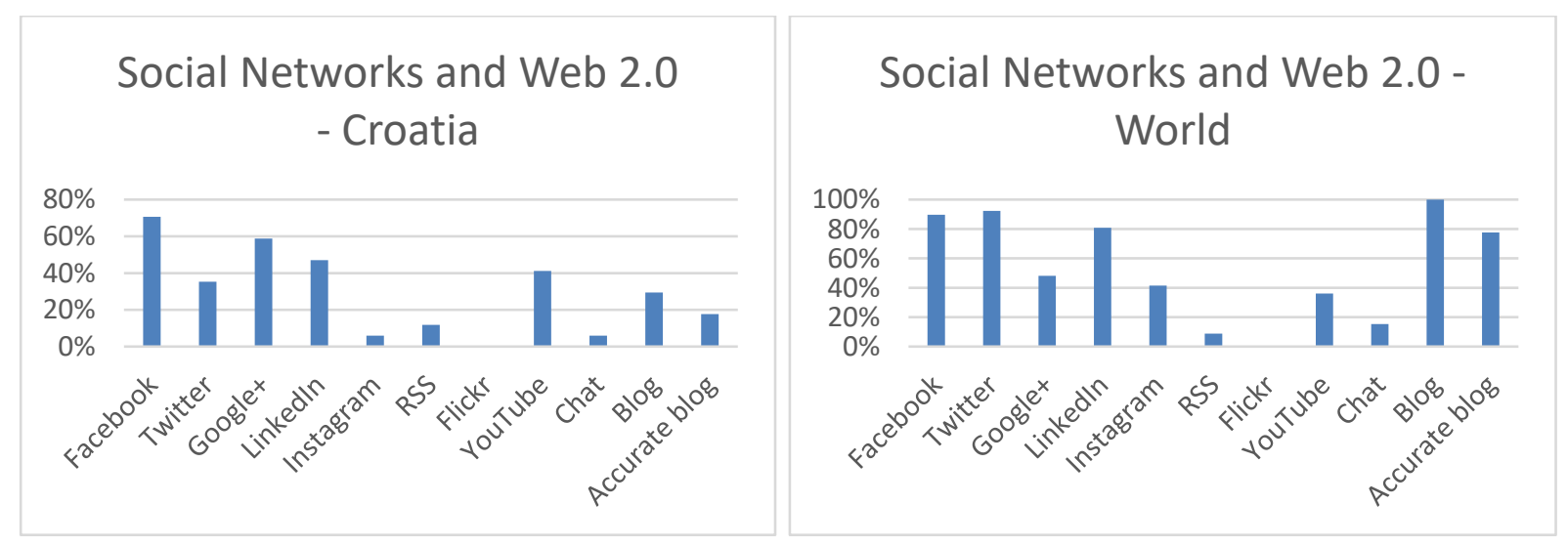

Fig. 3. Social Networks and Web 2.0

As for the international relations - according to figure 4, 25 websites (14\%) had a special space for media releases, and $151(83 \%)$ had a newsletter sign-up field. 8 websites showed information regarding their corporate social responsibility $(4 \%)$. 
24/7 customer support information was not present on either foreign Web site (0\%), which shows that it is undersood by everyone today that communication is constant. Difficulties reporting was possible on 133 websites (73\%), and 16 websites $(9 \%)$ had a special information department online. Customer support was mostly available through e-mail (183, $100 \%)$, phone $(181,99 \%)$, and chat $(29,16 \%)$.

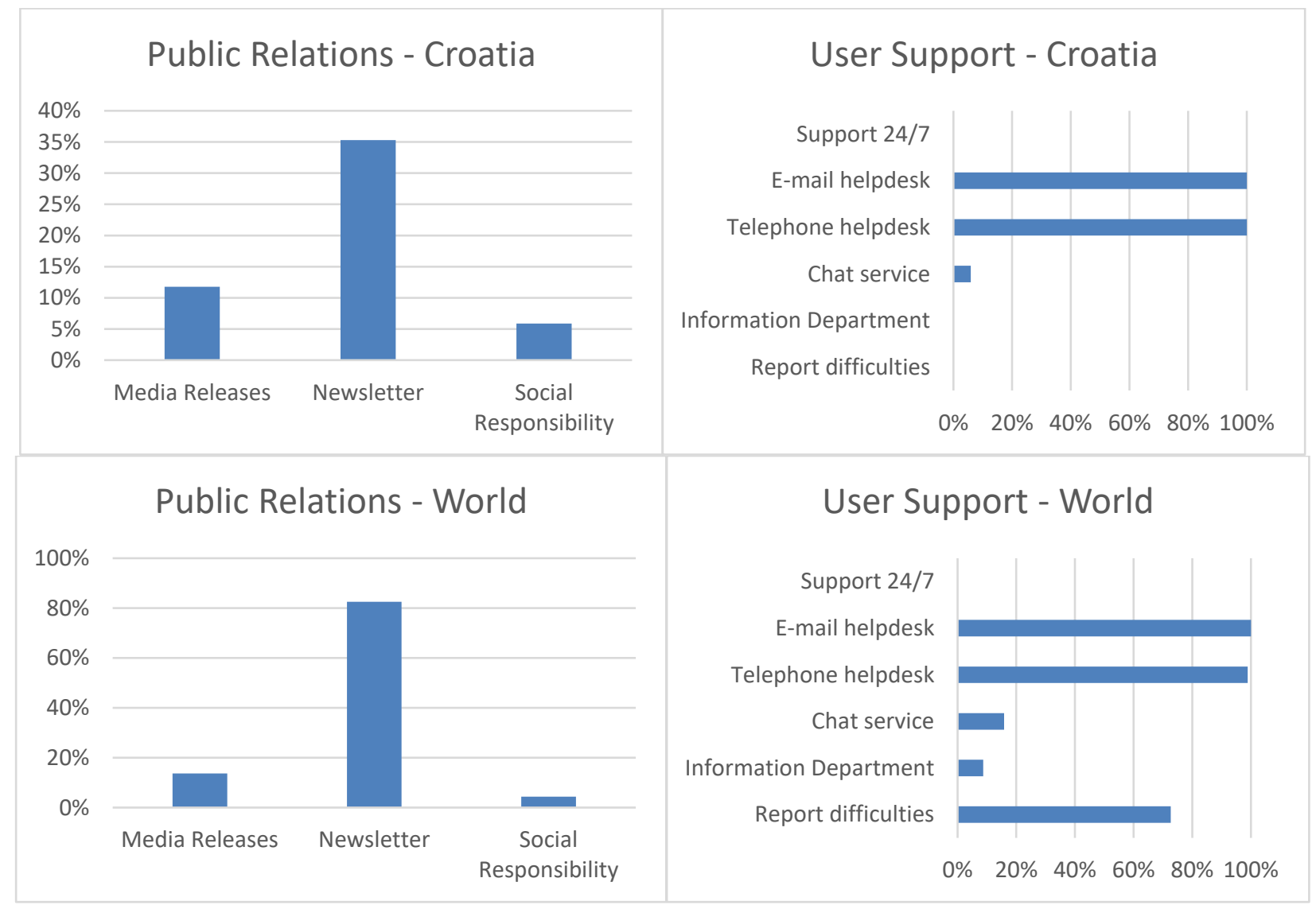

Fig. 4. Public Relations and User Support

All of the foreign websites that were analyzed $(183,100 \%)$, like in Croatia, as seen in figure 5, use photos on their websites, 157 (86\%) use animations, and 35 (19\%) have video content. All of the websites had a logo.

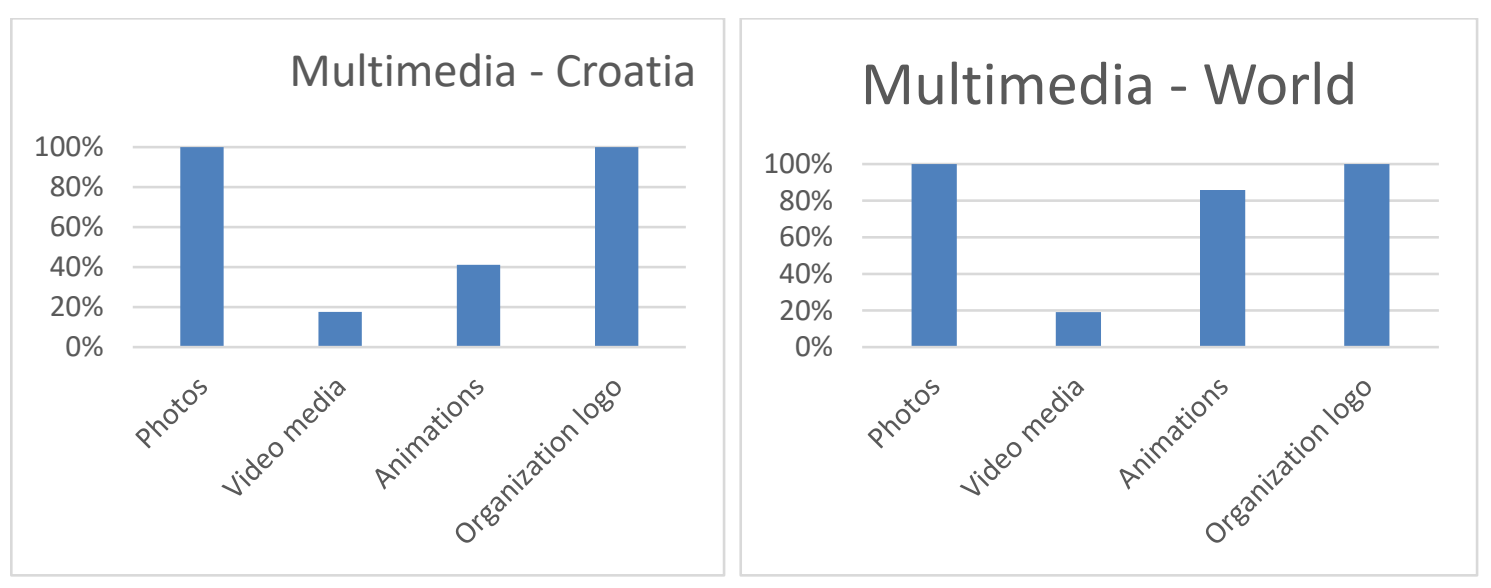

Fig. 5. Multimedia

46 websites (25\%) had a domain authority over 50, and $39(21 \%)$ had a page authority over 50.18 websites $(10 \%)$ had an originating country rank under 5.000, and $41(22 \%)$ had a global rank under 500.000. 71 websites $(39 \%)$ had a bounce rate under $50 \% .73 \%$ of websites had a landing page size under $5 \mathrm{MB}$, and $143(78 \%)$ of the landing pages loaded in under 3 seconds. 103 websites $(56 \%$ ) had a performance rate of over $80 \%$ (figure 6). 


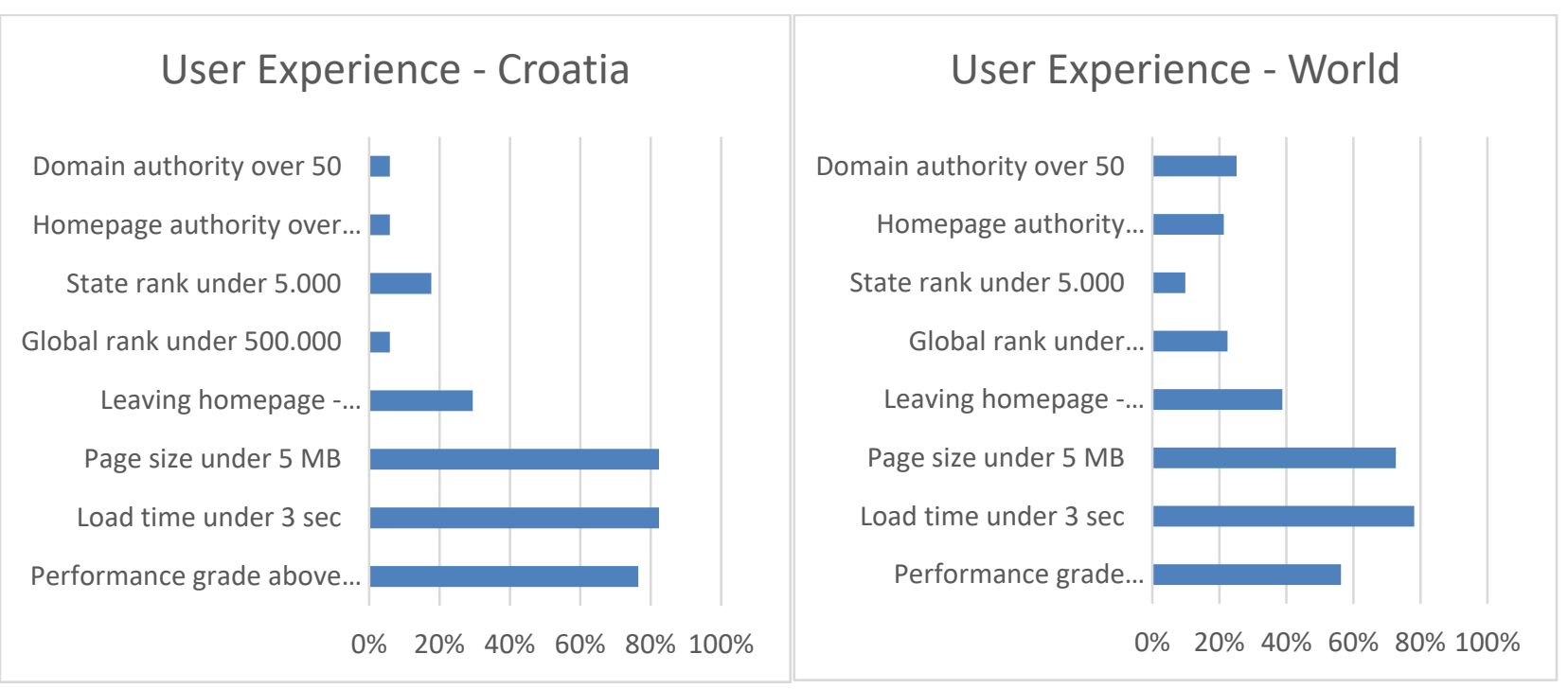

Fig. 6. User Experience

All of the foregin websites $(183,100 \%)$ used HTML, as well as Java (like in Croatia). 3 used ASP (2\%), 70 used PHP $(38 \%)$ and 102 used Flash (56\%). 50 websites (27\%) are available in more than 1 language, and 8 websites (4\%) use secure HTTP (https).

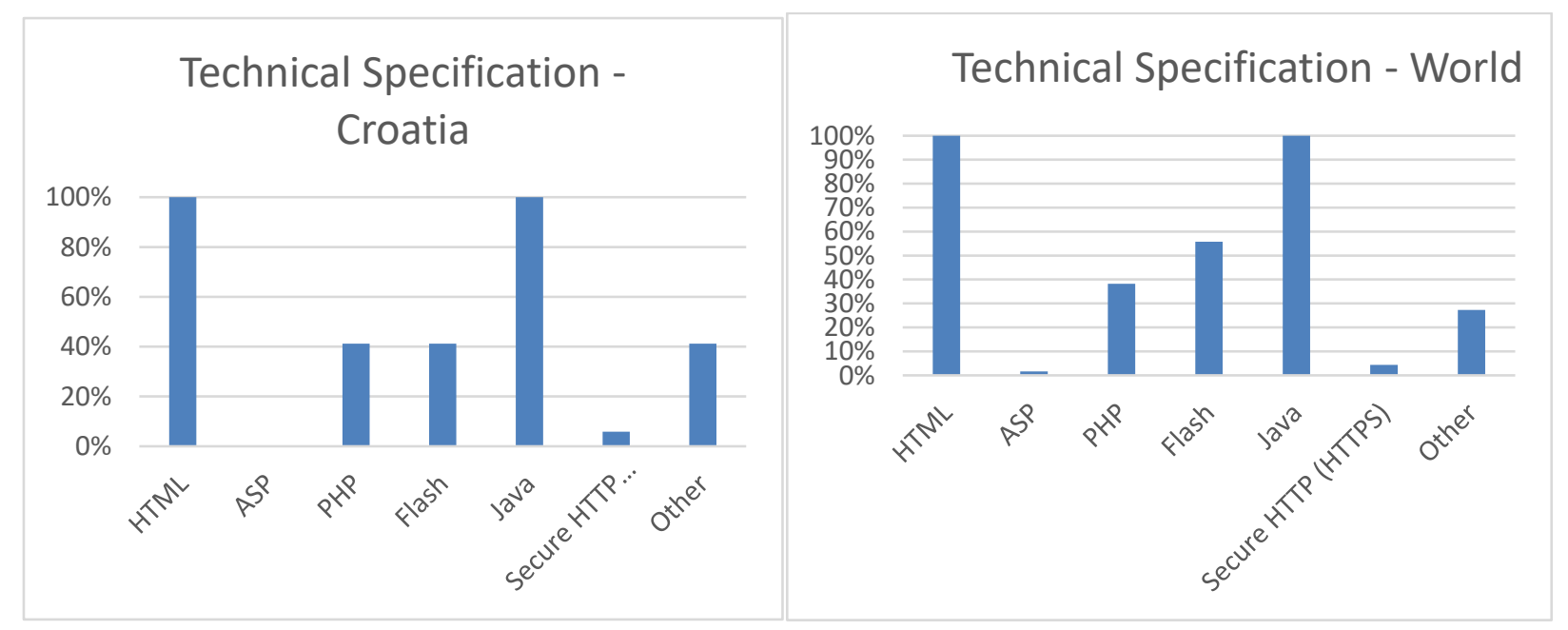

Fig. 7. Technical Specification

\section{Conclusion}

Activities of the organisation and event managements are changing at an accelerated rate, but because of that speed change, they can only be hard to understand and notice, especially in a situation when we need to plan and execute a lot of events and activites connected with them during the upcoming year.

New data suggest that users of events, i.e. those who attend them and consume them, increasingly interact online, so in that way they reserve or check information using the Internet and e-business.

No matter if it's through video content, web pages or event places, through social media or in other ways, event organisers who are capable of creating a high quality online presence will be the most successful in their intents.

Technology isn't just something which we will sometimes use when we want anymore, yet it is omnipresent and we use it $100 \%$ of the time nowadays, in other words, we could say that it is using us. It is necessary to use smartphones nowadays, tablets or computers / laptops in the process of event organisations, just like in many other activities. It is Internet and innovative digital technology which enabled replacing meeting in real life, but not fully. We need to incorporate technology to the real world and contact so that we could extract and get the maximum out of event organisations and real and virtual world.

In this work the research and results based on analysis of services and informations collected on web pages and organisation websites connected to the event organisations are presented. Analysis included 200 websites of the mentioned organisations, of which 17 are Croatian and 183 foreign websites, i.e. websites which operate outside Republic 
of Croatia. 183 of foreign websites include organisation websites which operate in United Kingdom, Republic of Ireland, Canada, Australia, India, Austria and South African Republic, since the presence on the Internet is of very high importance nowadays, it is important to present yourself well on your website, i.e. web pages. Users of services of mentioned organisations connected with event organisations use the Internet more and more in the process of using the services or searching the services, so there's nothing left to do other than to innovate and move from physical advertising and content presentations at any time, without the need for humans.

The listed results show how there's a lot of space for improvement for Croatian organisations which operate in the event organisation industry, since the first Croatian organisaton on the list of this research is on the $40^{\text {th }}$ spot out of 200 in total, and the last i.e. the $200^{\text {th }}$ is a Croatian organisation.

The one thing we need to work the most on is satisfying the user experience, and that can be done so that we decrease the loading time of the web page or website of important content on websites, and remove the unnecessary content. Also, presence on social media is very important nowadays, domain where Croatian organisations really falls short, in regard to foreign organisations. Generally, all the organisations fear the changes on social media, and that can be seen through the fact that Facebook is still the most popular social media for presentation from the aspect of event organisers, while the youth are focusing more and more on new social media like Instagram.

Furthermore, adaptation of websites is clean on mobile devices, but we are honestly dissapointed with low number of independent mobile applications which are especially in todays world very widespread.

Mobile devices and tablets are slowly taking the lead over Personal Computers and laptops because of their mobility, and every foreign start-up has atleast one application on mobile markets nowadays. That points towards the global trend which has to be tracked if the organisations want to stay relevant in the future.

Multimedia content is key in event organisations because people today look at experiences from previous events and based on them they judge the potential level of fun and profitability of events in the future.

Photography really is a massively used multimedia content because it is so widespread and easy to use, and it doesn't affect the size of a webpage and the loading time. Although video content is also very important, it affects the size of websites a lot so most of organisation outsource the video content on Internet tools like YouTube. That way they solve the loading problem, while the content is easily searchable on the whole internet.

Limitation of this paper is in the research sample due to fact that only webistes from selected countries were selected. Future analyses should be done from the perspective of customers. It should investigate the relationship between marketing activities and main strategies and activities of event management organizations.

\section{References}

[1] Tapscott, D. (1997). The Digital Economy: Promise and Peril In The Age of Networked Intelligence, McGraw-Hill, pp. 15.

[2] Spremić, M. (2017). Digitalna transformacija poslovanja. Sveučilište u Zagrebu / Ekonomski fakultet, pp. 38.

[3] Brynjolfsson, E. (2002). Understanding the Digital Economy: Data, Tools, and Research, MIT Press, pp. 9.

[4] Tapscott, D. (1997). Growing Up Digital: The Rise of the Net Generation, McGraw-Hill, pp. 34.

[5] Kehal, H. S.; Singh, V. P. (2005). Digital Economy: Impacts, Influences, and Challenges, Idea Group Pub., pp. 54.

[6] Waldfogel, J.; Peitz, M. (2012). The Oxford Handbook of the Digital Economy, Oxford University Press, pp. 118.

[7] Panian, Ž.; Strugar, I. „Informatizacija poslovanja“. Ekonomski fakultet Zagreb, Zagreb, 2013., pp. 27.

[8] Khurana, A. (2017). E-business vs. E-commerce: Understanding the Difference. [online]. The Balance. Available on https://www.thebalance.com/ebusiness-vs-ecommerce-1141573 Accessed on: 2017-08-27

[9] Bertels, A. „The Difference Between E-Business and e-Commerce“ [online], Computer World. Available on https://www.computerworld.com/article/2588708/e-commerce/e-commerce-the-difference-between-e-businessand-e-commerce.html Accessed on: 2017-08-29

[10] McCall, T. (2015). Is Your Organization an e-Business or d-Business?. [online]. Gartner. Available on http://www.gartner.com/smarterwithgartner/is-your-organization-an-e-business-or-d-business/ Accessed on: $2017-$ 08-29

[11] Greenstein, S; Tucker, C.; Goldfarb, A. (2015) Economic Analysis of the Digital Economy, National Bureau of Economic Research, pp. 26.

[12] Brynjolfsson, E.; McAfee, A. (2011). Race Against the Machine, MIT Press, pp. 119.

[13] Harris, M. (2015). Book review: 'The Internet Is Not the Answer' by Andrew Keen. Washington Post, pp. 79.

[14] Schultz, J.; Perzanowski, A. (2016). The End of Ownership: Personal Property in the Digital Economy, MIT Press, pp. 14.

[15] Huws, U. (2014). Labor in the Global Digital Economy: The Cybertariat Comes of Age, NYU Press, pp. 26.

[16] Kermek, D. (1997). Databases on the Internet. Journal of Information and Organizational Sciences [online], 21(2). Available on http://hrcak.srce.hr/index.php?show=clanak\&id_clanak_jezik=117455 Accessed on: 2017-08-11 
[17] University of Pittsburgh. (2003). E-Business Resource Group Security Guidelines. [online]. Available on http://www.cfo.pitt.edu/ebusiness/arEBSecurityGuide.pdf, Accessed on: 2017-08-28

[18] Brynjolfsson, E. (2014). The Second Machine Age: Work, Progress, and Prosperity in a Time of Brilliant Technologies, MIT Press, pp. 46.

[19] Westfall, J. (2010). Privacy: Electronic Information and the Individual. Santa Clara University, Markkula Center for Applied Ethics, pp. 187.

[20] Ibrahimpašić, B., Liđan, E. (2011). Digitalni potpis. Osječki matematički list [online], 10(2). Available on http://hrcak.srce.hr/index.php?show=clanak\&id_clanak_jezik=100091 Accessed on: 2017-07-23

[21] Karlsson, C. (2010). The Emerging Digital Economy: Entrepreneurship, Clusters, and Policy, Springer Berlin Heidelberg, pp. 26.

[22] Coltman, T., Devinney, T., M., Latukefu, A., Midgley, D.,F. (2001). E - business: Revolution, Evolution or Hype?. [online]. JSTOR. Dostupno na: http://www.jstor.org/stable/41166111 Accessed on: 2017-08-02

[23] Jamsa, K. (2013). Cloud Computing. Jones \& Bartlett Learning, Burlington, MA, pp. 34.

[24] O'Reilly, T. (2005). What Is Web 2.0. [online]. O'Reilly Network. Available on http://www.oreilly.com/pub/a/web2/archive/what-is-web-20.html Accessed on: 2017-08-28

[25] Panian, Ž. (2000). Bogatsvo Interneta. Zagreb: Strijelac

[26] Spremić, M. (2017). Digitalna transformacija poslovanja. Zagreb: Ekonomski fakultet u Zagrebu, pp. 38.

[27] Mandić, M. (2009). Privacy and security in E-commerce. Tržište [online], 21(2). Available on http://hrcak.srce.hr/index.php?show=clanak\&id_clanak_jezik=81070 Accessed on: 2017-07-18

[28] Rowley, M. (2017). How mobile technology is transforming lives in rural India. [online]. TechCrunch. Available on https://techcrunch.com/2017/02/19/how-mobile-technology-is-transforming-lives-in-rural-india/ Accessed on: 2017-08-28

[29] Matysek, M., Adamek, M., Karafiat, T. (2016). The Mobile Monitoring and Control of Real Systems, Proceedings of the 26th DAAAM International Symposium, pp.0104-0108, B. Katalinic (Ed.), Published by DAAAM International, ISBN 978-3-902734-07-5, ISSN 1726-9679, Vienna, Austria

[30] Spremic, M., Kokolek, N., Jakovic, B., Simurina, J. (2015). Marketing and Commercial Activities Offered on Websites of European Union Banks. International journal of social, behavioral, educational, economics and management engineering. 9, 6; pp. 1757-1763. 